\section{Freesia Responds to Preplant Flurprimidol and Paclobutrazol Corm Soaks}

\author{
William B. Miller ${ }^{1}$ \\ School of Integrative Plant Science, Horticulture Section, Cornell University, \\ 134 Plant Sciences Building, Ithaca, NY 14853
}

Additional index words. floriculture, geophytes, height control, plant growth regulators

\begin{abstract}
Experiments conducted over 3 years have indicated the efficacy of preplant paclobutrazol or flurprimidol corm soaks for leaf and scape growth control in potted freesia (Freesia hybrida). A range of cultivars subjected to 30- to 60-min soaks in 60 to 120 $\mathrm{mg} \cdot \mathrm{L}^{-1}$ paclobutrazol and 10 - to 30 -min soaks in 10 to $30 \mathrm{mg} \cdot \mathrm{L}^{-1}$ flurprimidol resulted in significant and commercially relevant height control without reducing the number of flowering scapes. Cultivars varied in their response to the plant growth regulators (PGRs), suggesting that individual grower trials will be necessary to develop an optimum treatment for each location.
\end{abstract}

Worldwide, freesia is mainly grown as a cut flower, and it is well-adapted to cooler climates. The plant is grown from corms. Using temperature treatments after lifting, flower induction and initiation can be controlled for year-round flowering.

Freesia is a niche crop for potted plant growers. In North America, most plants are grown in a narrow coastal band in California. The cool maritime climate allows outdoor production of compact, high-quality plants. There has long been interest in expanding production to other areas in North America, namely the upper midwest and northeast, where cool winters are ideal for the production of a low-energy, intensive crop. When grown in relatively low-light greenhouses (as in the northeast), however, freesia plants often elongate excessively and the plant quality suffers.

Gianfagna and Wulster (1986) first showed the efficacy of paclobutrazol or ancymidol for freesia growth control. Using five cultivars, drenches of these PGRs (5 mg a.i./ pot) reduced plant height by $40 \%$ to $60 \%$ and inflorescences up to $93 \%$. There was no effect on the number of flowering scapes, although the treated plants flowered $\approx 10 \mathrm{~d}$ after the controls. Preplant soaks in $250 \mathrm{mg} \cdot \mathrm{L}^{-1}$ paclobutrazol were even more effective than substrate drenches. Therefore, it was concluded that "reduced immersion times or rates should result in simple and inexpensive" height control for freesia Gianfagna and Wulster (1986).

Wulster et al. (1989) showed that an average daily temperature (ADT) of $20{ }^{\circ} \mathrm{C}$ in the greenhouse caused taller plants than did

Received for publication 24 Apr. 2018. Accepted for publication 24 May 2018.

I gratefully acknowledge Amanda van den Bosch and Roos de Wit (Dutch interns) and Allison Hrycik (Cornell student) for their assistance with these experiments.

${ }^{1}$ Corresponding author. E-mail: wbm8@cornell. edu. lower temperatures $\left(15^{\circ} \mathrm{C}\right.$ ADT $)$, and plants grown at $10{ }^{\circ} \mathrm{C}$ ADT were even shorter. Clearly, forcing temperature is an important component of plant height, and temperature control is critical for potted freesia production. Ancymidol drenches (applied 1 week after planting) up to $3 \mathrm{mg} /$ pot were effective, but less so at warmer temperatures, and the effects varied by cultivar. Regarding freesia production, "from a quality perspective, chemical height control is not an adequate substitute for appropriate greenhouse environment" Wulster et al. (1989).

Berghoef and Zevenbergen (1990) found that ancymidol drenches at 2 to $4 \mathrm{mg} / \mathrm{pot}$ applied 2 weeks after planting were effective for freesia height control in October plantings. Under similar growing conditions, the scape and leaf lengths decreased as the ancymidol concentration increased from 50 to $200 \mathrm{mg} \cdot \mathrm{L}^{-1}$ and as the soak length was increased from 1 to $10 \mathrm{~h}$. Therefore, the concept of very long soaks may have been derived from their work.

De Hertogh and Milks (1990) found that freesia 'Aida' was responsive to ancymidol at a concentration of $200 \mathrm{mg} \cdot \mathrm{L}^{-1}$, but this is too expensive for commercial use because the fullstrength commercial product is only available as $264 \mathrm{mg} \cdot \mathrm{L}^{-1}$. Paclobutrazol soaks (4-h soaks, cultivar Aida) were effective at $50 \mathrm{mg} \cdot \mathrm{L}^{-1}$, with increasing effects to $200 \mathrm{mg} \cdot \mathrm{L}^{-1}$. Drenches of $5 \mathrm{mg} /$ pot a.i. were similar to $100-\mathrm{mg} \cdot \mathrm{L}^{-1}$ soaks. When soaked in 100 to $400 \mathrm{mg} \cdot \mathrm{L}^{-1}$ paclobutrazol, 'Rossini' plant height decreased as the soak length increased from 1 to $4 \mathrm{~h}$. Finally, drying times after soaks of only $2 \mathrm{~h}$ were suggested because longer drying times resulted in unspecified "erratic" results.

Wulster and Gianfagna (1991) showed that preplant cold storage at $5{ }^{\circ} \mathrm{C}$ for 2 to 4 weeks reduced scape height, leaf length, and the number of days to flower after planting. The source material was Rutgers-grown corms that had been stored at $30{ }^{\circ} \mathrm{C}$ for 15 weeks to break dormancy before cold storage. They concluded that the time to flower initiation needed to be determined, especially in relation to the cold treatment. Ancymidol was used as drenches of 1 to $3 \mathrm{mg} /$ pot, but it is too expensive for commercial use. Ancymidol at $3 \mathrm{mg} /$ pot reduced the scape height and leaf length by $>50 \%$ and delayed flowering by $\approx 9 \mathrm{~d}$.

De Hertogh (1996) listed preplant corm soak guidelines for a variety of freesia cultivars. Soaking for $1 \mathrm{~h}$ in 50 to $100 \mathrm{mg} \cdot \mathrm{L}^{-1}$ paclobutrazol was recommended for $\approx 40 \%$ of the cultivars; for $\approx 60 \%$ of the cultivars, the soak recommendations involved 200 to $300 \mathrm{mg} \cdot \mathrm{L}^{-1}$. These rates appeared to have been developed in a warm climate (i.e., North Carolina) (De Hertogh and Milks, 1990).

Cavins and Erickson (2004) reported that the temperature of the soaking solution affected the efficacy of flurprimidol corm soaks. When performing 30 - to 60 -min soaks, room temperature or warmer solutions ( 17 to $\left.32{ }^{\circ} \mathrm{C}\right)$ were more effective than cold $\left(7^{\circ} \mathrm{C}\right)$ solutions. Flurprimidol at $54 \mathrm{mg} \cdot \mathrm{L}^{-1}$ and 77 $\mathrm{mg} \cdot \mathrm{L}^{-1}$ caused a $30 \%$ reduction in height with tepid and cold solutions, respectively. The soak length had no effect on the concentration of flurprimidol that is needed to reduce height by a targeted $30 \%$. As expected, the cultivar response varied significantly.

Much of the literature regarding freesia growth regulation involved now-extinct cultivars or warmer climates, where warmer greenhouse temperature interact with leaf and scape growth, thereby requiring greater PGR concentrations. Additional information about PGR use is needed to expand freesia production in greenhouses in the northern United States. The present work was performed to obtain PGR information regarding modern cultivars grown in northern greenhouse conditions and to further evaluate flurprimidol as a potential PGR for potted freesia.

\section{Materials and Methods}

Experiments were conducted during three growing seasons. Corms were obtained from The Netherlands (shipped by air freight) that had been given unspecified preshipment storage regimes. In all experiments, 9 corms were used per $15-\mathrm{cm}$ pot, with 6 replications (pots) per treatment. Plants were initially grown pot-to-pot; then, they were spaced on $25-\mathrm{cm}$ centers when the foliage was $\approx 15 \mathrm{~cm}$ tall. Each experiment was conducted as a completely randomized design. Data were collected on the anthesis date of each pot (when two or more scapes had at least one open flower), including scape length (pot rim to the top of the oldest flower petal part), typical leaf length (pot rim to the end of the leaf), and the number of flowering scapes per pot. Data from each experiment were analyzed using linear and quadratic regression (JMP; SAS Institute, Inc., Cary, NC).

$P G R$ concentration experiments, years 1 and 2. Before planting, corms were soaked for $1 \mathrm{~h}$ in paclobutrazol (Fine Americas, Walnut Creek, CA) or flurprimidol (SePRO, Carmel, IN) solutions prepared with reverse-osmosis water at $20^{\circ} \mathrm{C}$. In year 1 , concentrations of 
Table 1. Effects of flurprimidol and paclobutrazol preplant soaks $(1 \mathrm{~h})$ on growth and flowering of 5 freesia cultivars in year 1.

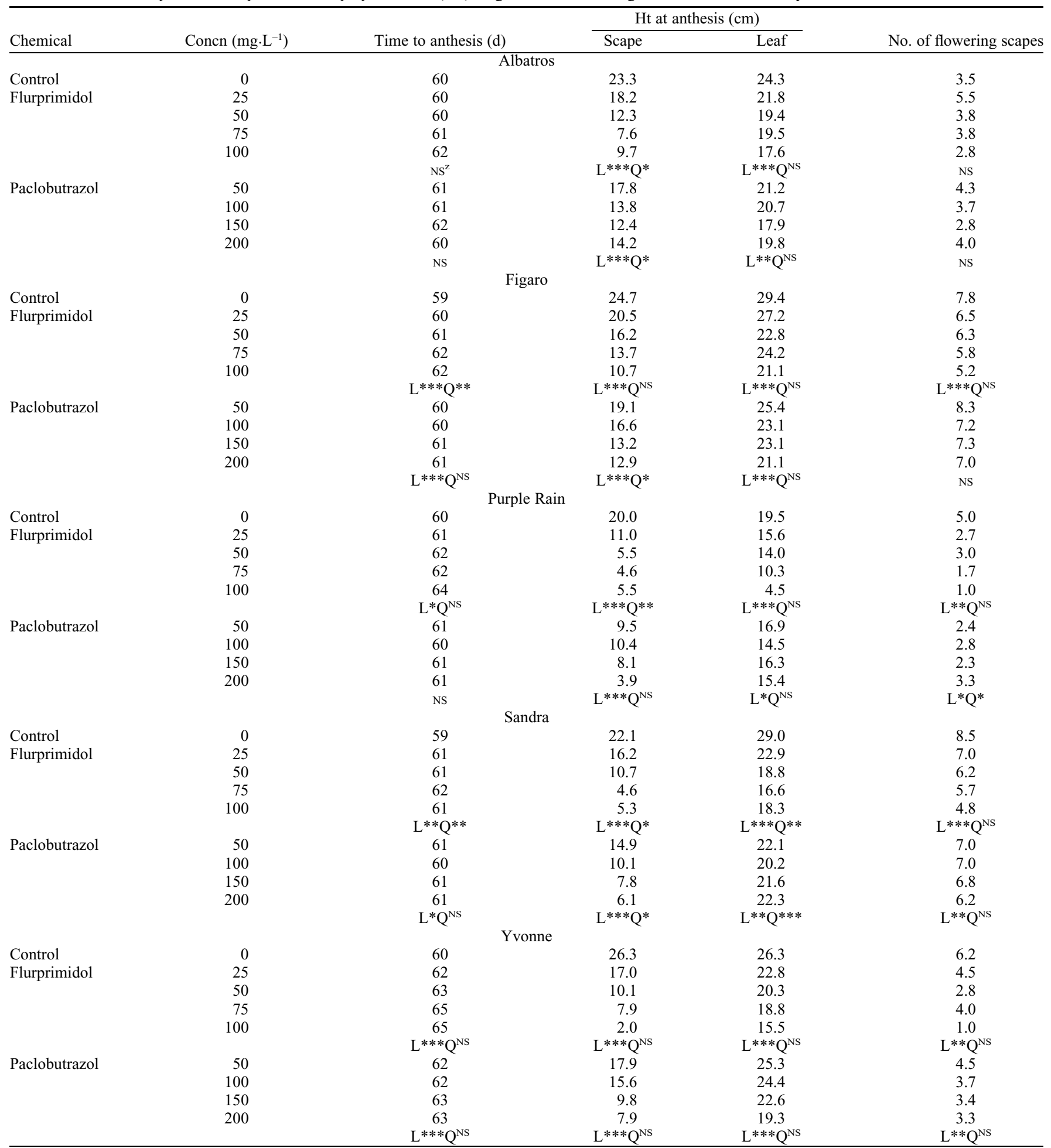

${ }^{\mathrm{z}}$ Significance of linear $(\mathrm{L})$ or quadratic $(\mathrm{Q})$ regression: NS, ${ }^{*}, * *, * *$ denotes nonsignificant or significant at $P \leq 0.05,0.01$, or 0.001 , respectively.

50 to $200 \mathrm{mg} \cdot \mathrm{L}^{-1}$ paclobutrazol and 25 to 100 $\mathrm{mg} \cdot \mathrm{L}^{-1}$ flurprimidol were tested on cultivars Albatros, Figaro, Purple Rain, Sandra, and Yvonne. In year 2, concentrations were reduced to 30 to 120 and 15 to $60 \mathrm{mg} \cdot \mathrm{L}^{-1}$, respectively, and cultivars were Albatros, Blue Bayou, Figaro, Honeymoon, and Texas.

Corms were planted 29 Mar. or 4 Feb. (year 1 and year 2, respectively) using LM111 substrate (Lambert Peat Moss, Inc.,
Riviere-Ouelle, Quebec) and grown in a glass greenhouse with normal cultural conditions. The greenhouse ADT averaged $16.1{ }^{\circ} \mathrm{C}$ in year 1 and $12.7^{\circ} \mathrm{C}$ in year 2 based on 15 -min readings from shielded and aspirated dataloggers (Onset Computer Corp., Bourne, $\mathrm{MA}$ ) in an aspirated box $0.5 \mathrm{~m}$ above crop level.

Length of preplant soaks, year 2. The effects of the soak length were evaluated using $60 \mathrm{mg} \cdot \mathrm{L}^{-1}$ flurprimidol and soak lengths of 10,30, and $60 \mathrm{~min}$. Controls were soaked in water for $10 \mathrm{~min}$. Corms were allowed to drain and air dry for $1 \mathrm{~h}$; then, they were planted as described previously. Soaking and planting were performed on $4 \mathrm{Feb}$.

$P G R$ concentration, year 3 . Corms were soaked on $23 \mathrm{Jan}$. in 10,20 , and $30 \mathrm{mg} \cdot \mathrm{L}^{-1}$ flurprimidol or 33,66 , and $99 \mathrm{mg} \cdot \mathrm{L}^{-1}$ paclobutrazol. The duration of preplant soaking 
Table 2. Effects of 1-h preplant soaks in different concentrations of paclobutrazol and flurprimidol on growth and flowering of 5 freesia cultivars in year 2.

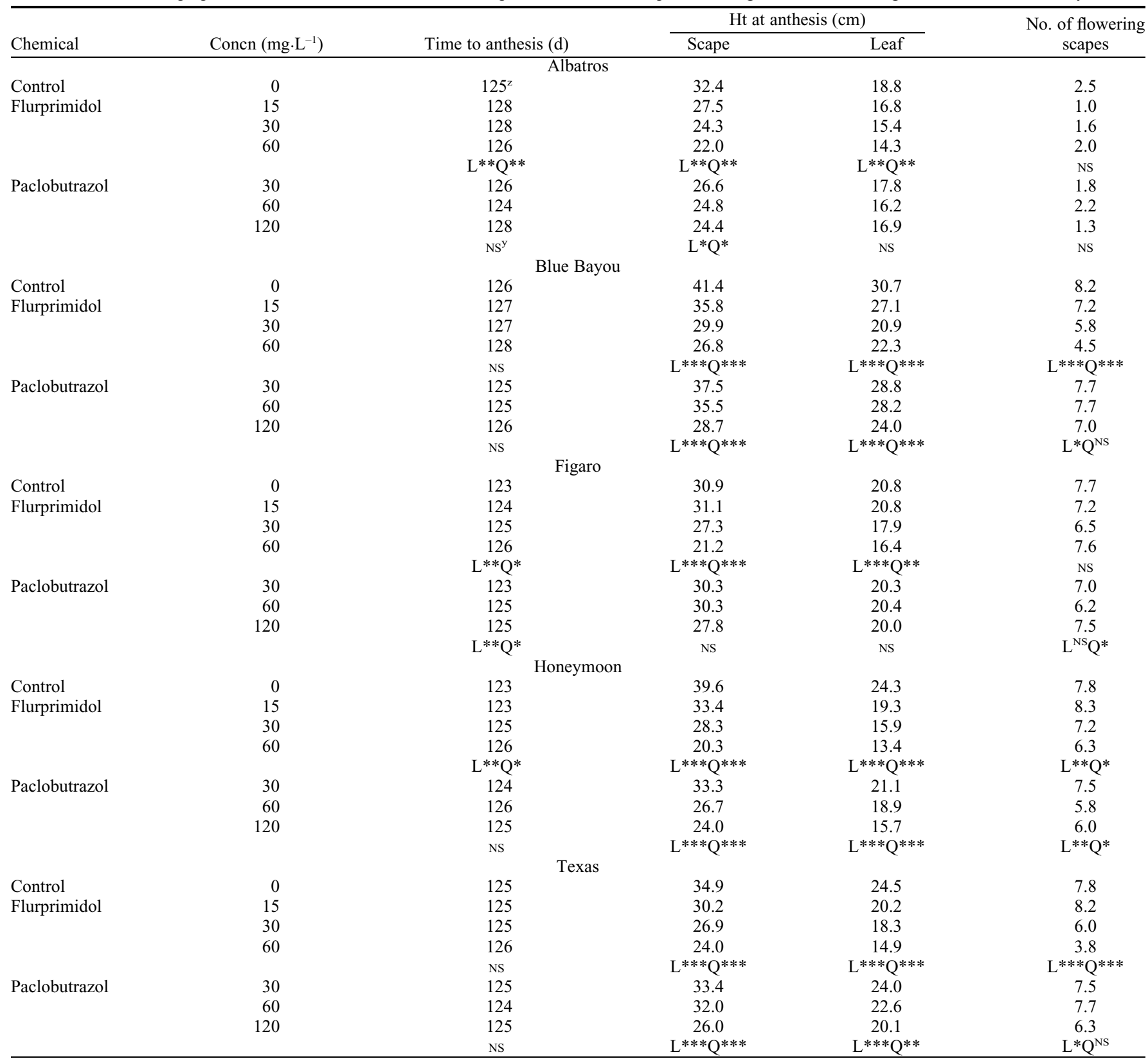

${ }^{\mathrm{z}}$ Significance of linear (L) or quadratic (Q) regression: NS, ${ }^{*}, * *, * *$ denotes nonsignificant or significant at $P \leq 0.05,0.01$, or 0.001 , respectively.

was evaluated with $30 \mathrm{mg} \cdot \mathrm{L}^{-1}$ flurprimidol by soaking corms for 5,10 , or $30 \mathrm{~min}$; controls were soaked in water for $10 \mathrm{~min}$. The cultivars were Blue Bayou, Diamond Star, Figaro, Honeymoon, and Texas. Greenhouse ADT during the experiment was $13{ }^{\circ} \mathrm{C}$.

Length of preplant soaks, year 3 . The effects of the soak length were evaluated using $30 \mathrm{mg} \cdot \mathrm{L}^{-1}$ flurprimidol and soak lengths of 5, 10, and $30 \mathrm{~min}$. Controls were soaked in water for $10 \mathrm{~min}$. Soaking and planting were performed on 24 Jan. Corms were allowed to drain and air-dry for $1 \mathrm{~h}$; then, they were planted as described previously.

\section{Results}

PGR concentration, year 1 . Tested soak concentrations $(1 \mathrm{~h})$ were 50 to $200 \mathrm{mg} \cdot \mathrm{L}^{-1}$ paclobutrazol and 25 to $100 \mathrm{mg} \cdot \mathrm{L}^{-1}$ flurprimidol $(1 \mathrm{~h})$. For all cultivars, the scape and leaf length were highly affected by the PGR treatments (Table 1). Both flurprimidol and paclobutrazol corm soaks significantly reduced the scape and leaf height in a linear manner compared with the untreated control plants. In many cases, the quadratic effect was also significant, but generally less so than the linear component. In many cases, the amount of growth control was excessive and plants were aesthetically too small relative to the container when flowering. PGR treatments delayed flowering for four of the five cultivars, with the largest difference being $5 \mathrm{~d}$, which was of little commercial significance. Four of five cultivars also showed a reduction in the number of flowering scapes as a result of the treatments. This happened with both PGRs for 'Purple Rain', 'Sandra', and 'Yvonne', and with flurprimidol for 'Figaro'. The number of flowering scapes was unaffected in 'Albatros' (Table 1).

$P G R$ concentration, year 2. Tested soak concentrations $(1 \mathrm{~h})$ were decreased from the previous year to 30 to $120 \mathrm{mg} \cdot \mathrm{L}^{-1}$ paclobutrazol and 15 to $60 \mathrm{mg} \cdot \mathrm{L}^{-1}$ flurprimidol. Both PGRs reduced the final scape and leaf length, with significant linear and quadratic responses (Table 2). Two exceptions were 'Albatros' (paclobutrazol had no effect on leaf length) and 'Figaro' (paclobutrazol had no effect on scape and leaf length). Three of the cultivars showed significant reductions in the number of flowering scapes by both chemicals; there was no effect on 'Albatros' and flurprimidol had no effect on 'Figaro'. There were inconsistent effects on days to 
Table 3. Effects of preplant soaks in $60 \mathrm{mg} \cdot \mathrm{L}^{-1}$ flurprimidol on growth and flowering of 5 freesia cultivars in year 2.

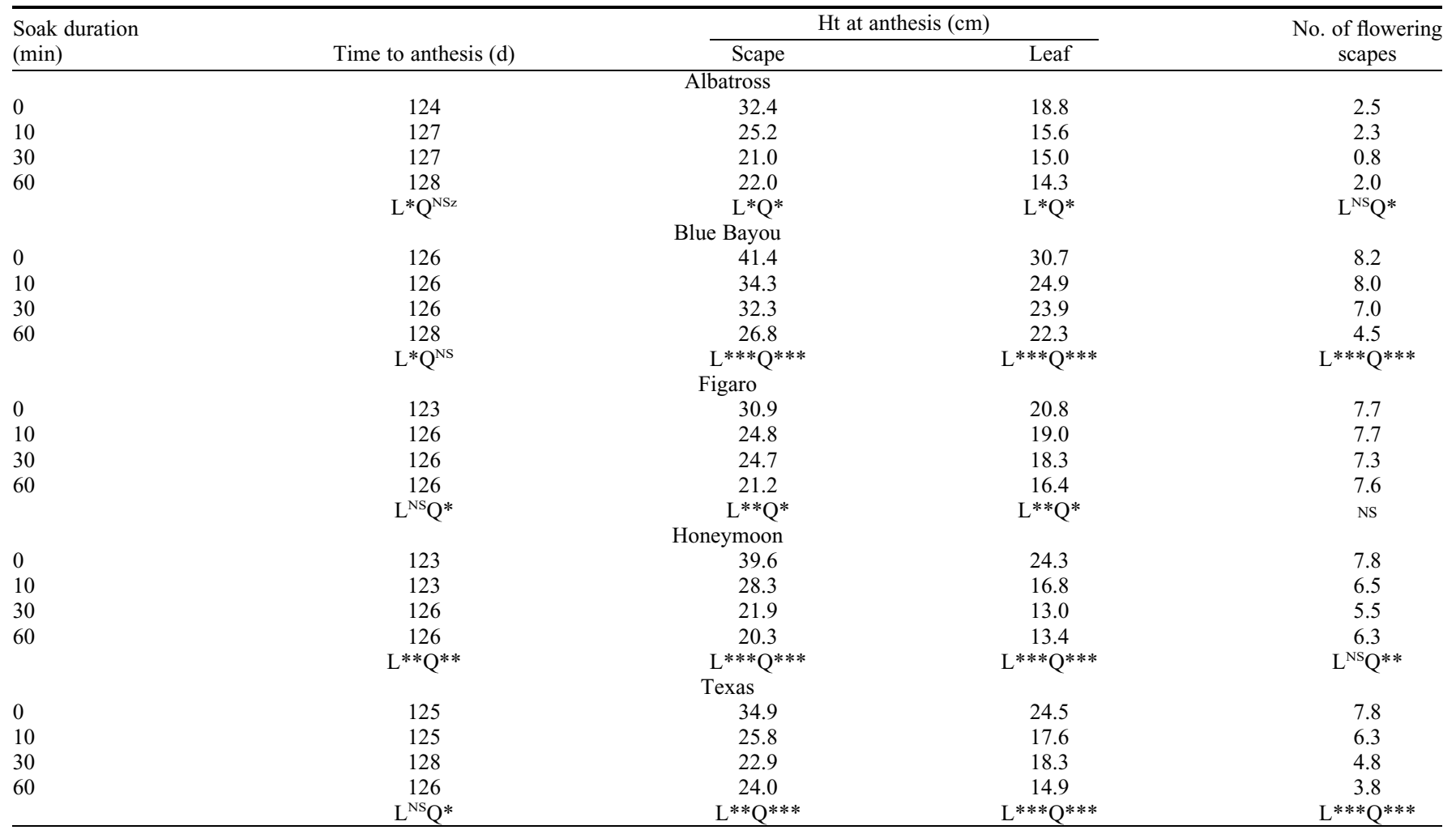

${ }^{\mathrm{z}}$ Significance of linear (L) or quadratic (Q) regression: NS, ${ }^{*}, * * * * *$ denotes nonsignificant or significant at $P \leq 0.05,0.01$, or 0.001 , respectively.

flowering, but the largest delay was $4 \mathrm{~d}$; however, this was of little commercial significance.

Length of preplant soaks, year 2. To explore the potential for decreasing the soak duration, corms were soaked for 10 , 30 , or $60 \mathrm{~min}$ in $60 \mathrm{mg} \cdot \mathrm{L}^{-1}$ flurprimidol. Results indicated that increasing the soak durations led to shorter scapes and leaves in all cultivars, and that longer soaks decreased the number of scapes to a greater degree than shorter soaks (Table 3). This was true for four of the five cultivars; however, with 'Figaro', the soak duration had no effect on the number of scapes. Increasing soak durations also delayed flowering, but the largest difference was only $4 \mathrm{~d}$; again, this was of little commercial significance (Table 3 ).

$P G R$ concentration, year 3. Tested soak concentrations were 33 to $99 \mathrm{mg} \cdot \mathrm{L}^{-1}$ paclobutrazol and 10 to $30 \mathrm{mg} \cdot \mathrm{L}^{-1}$ flurprimidol ( 30 $\min )$. For four of the cultivars, there were significant linear and quadratic decreases in the scape and leaf length as the concentration of either PGR increased (Table 4). For 'Figaro', paclobutrazol had no effect at the concentrations tested, and flurprimidol had no effect on leaf length (Table 4). In this experiment, two of the cultivars (Blue Bayou and Diamond Star) showed no response in number of scapes to the concentration of PGR (Table 4). 'Figaro' and 'Texas' exhibited a significant decrease in flower scapes as the flurprimidol concentration increased, but paclobutrazol had no effect (Table 4). As in past years, increasing soak durations delayed flowering, but the largest difference was $6 \mathrm{~d}$; this was probably of little commercial significance (Table 4).

Length of preplant soaks, year 3. Corms were soaked in $30 \mathrm{mg} \cdot \mathrm{L}^{-1}$ flurprimidol for 5 to $30 \mathrm{~min}$. At this concentration, increasing the soak duration linearly and quadratically decreased the scape and leaf length in four of the five cultivars (Table 5). 'Figaro' was less responsive, and only the scape length was affected by the treatments. Four of the five cultivars showed no reduction in the number of scapes; however, Figaro was an exception. As in past years, the treatments caused slight delays in flowering as the soak duration increased.

\section{Discussion}

Effective and consistent growth regulation of greenhouse-grown potted freesia has been a topic of interest for more than 30 years (Gianfagna and Wulster, 1986). The optimum environmental conditions for potted freesia production (high levels of light and cool temperatures) are often difficult to achieve in northern greenhouses. In midwinter, when temperature control is feasible, light levels are less than optimum; in early spring, when there is adequate natural light, outdoor temperatures can vary widely and can result in greenhouse air temperatures well above optimum. Wulster et al. (1989) cautioned that PGR use for height control is not a substitute for a proper greenhouse environment (in this case, cool temperatures); however, there remains interest, especially as newer cultivars are developed, in PGR use for potted freesia.

The present work demonstrated that effective control of the scape and leaf elongation can be obtained with preplant corm soaks in paclobutrazol, with an effective range of 60 to $120 \mathrm{mg} / \mathrm{L}$ and soak times of 30 to 60 $\min$. These concentrations are notably lower than those reported by many previous studies of freesia (De Hertogh, 1996; De Hertogh and Milks, 1990; Gianfagna and Wulster, 1986). This could be attributable to the use of different cultivars or to greenhouse environmental conditions and growing regions. Ultimately, it is not possible to know the specific reasons. For greenhouse growers in northern states, the present data represent an appropriate starting point for paclobutrazol treatment of this crop.

Cavins and Erickson (2004) found that the water temperature had a significant effect on the efficacy of flurprimidol soaks; a greater concentration was needed at lower temperatures $\left(7^{\circ} \mathrm{C}\right.$ vs. 17 to $\left.32{ }^{\circ} \mathrm{C}\right)$. Furthermore, the effects of soaks for 30 and $60 \mathrm{~min}$ did not differ. During our study, all corms were treated at $20 \pm 2{ }^{\circ} \mathrm{C}$. The lack of additional inhibition with longer soaks in the Cavins and Erickson work agreed with the results of the present work because few additional growth regulation effects were seen between 30 - and 60-min soaks (Table 3).

The present results indicated the efficacy of flurprimidol at concentrations somewhat lower than those reported by Cavins and 
Table 4. Effects of 30-min preplant soaks in different concentrations of paclobutrazol and flurprimidol on growth and flowering of 5 freesia cultivars in year 3.

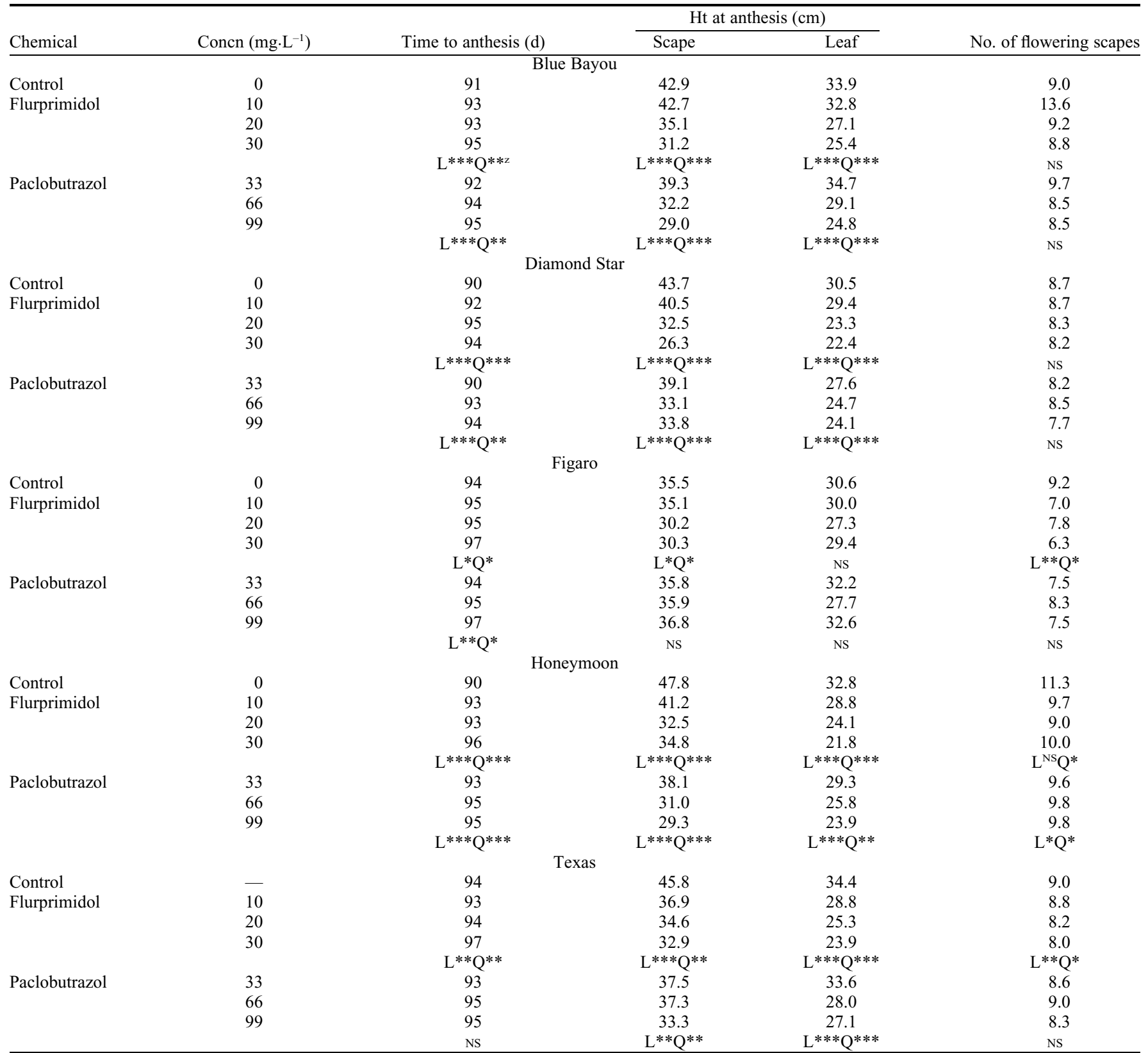

${ }^{\mathrm{z}}$ Significance of linear (L) or quadratic (Q) regression: NS, ${ }^{*}, * *, * *$ denotes nonsignificant or significant at $P \leq 0.05,0.01$, or 0.001 , respectively.

Erickson (2004). For example, flurprimidol was effective in the range of 10 to $30 \mathrm{mg} \cdot \mathrm{L}^{-1}$ for 10 to $30 \mathrm{~min}$ in most of the present cultivars. Potential reasons for this could be the differences in corm preparation before delivery or differences in the growing environment (temperature and light level). Ultimately, although flurprimidol was more effective at lower concentrations than paclobutrazol was, the choice should be based on economic considerations.

\section{Literature Cited}

Berghoef, J. and A.P. Zevenbergen. 1990. The effect of precooling, environmental factors and growth-regulating substances on plant height of Freesia as a pot plant. Acta Hort. 266:251-257.

Cavins, T.J. and P.I. Erickson. 2004. Freesia response to flurprimidol corm soaks. HortScience 39:664.

De Hertogh, A.A. 1996. Holland bulb forcer's guide. Alkemade Printing BV, Lisse, The Netherlands.

De Hertogh, A.A. and R. Milks. 1990. Forcing Dutch-grown freesias as potted plants in the U.S. and Canada. Acta Hort. 266:115-122.
Gianfagna, T.J. and G.J. Wulster. 1986. Growth retardants as an aid to adapting Freesia to pot culture. HortScience 21:263-264.

Wulster, G.J., S. Cartwright, and T.J. Gianfagna. 1989. The effects of greenhouse temperature and ancymidol concentration on height and flowering time of Freesia hybrid grown as a container plant. Acta Hort. 252:97-103.

Wulster, G.J. and T.J. Gianfagna. 1991. Freesia hybrida respond to ancymidol, cold storage of corms, and greenhouse temperatures. HortScience 26:1276-1278. 
Table 5. Effects of preplant corm soaks in $30 \mathrm{mg} \cdot \mathrm{L}^{-1}$ flurprimidol on growth and flowering of 5 freesia cultivars in year 3.

\begin{tabular}{|c|c|c|c|c|}
\hline \multirow[b]{2}{*}{ Soak duration (min) } & \multirow[b]{2}{*}{ Time to anthesis (d) } & \multicolumn{2}{|c|}{$\mathrm{Ht}$ at anthesis $(\mathrm{cm})$} & \multirow[b]{2}{*}{ No. of flowering scapes } \\
\hline & & Scape & Leaf & \\
\hline Control $^{z}$ & 91 & 42.9 & 33.9 & 9.0 \\
\hline 5 & 94 & 39.1 & 28.1 & 9.3 \\
\hline \multirow[t]{3}{*}{30} & 95 & 31.2 & 25.4 & 8.8 \\
\hline & $\mathrm{L}^{* *} \mathrm{Q} * * * \mathrm{y}$ & $\mathrm{L} * * * \mathrm{Q} * * *$ & $\mathrm{~L}^{* * *} \mathrm{Q} * * *$ & NS \\
\hline & & Diamond Star & & \\
\hline 10 & 93 & 33.9 & 22.6 & 8.3 \\
\hline \multirow[t]{3}{*}{30} & 94 & 26.3 & 22.4 & 8.2 \\
\hline & $\mathrm{L}^{*} \mathrm{Q}^{* *}$ & $\mathrm{~L}^{* * *} \mathrm{Q} * * *$ & $\mathrm{~L}^{*} \mathrm{Q} * * *$ & NS \\
\hline & & Figaro & & \\
\hline Control & 94 & 35.5 & 30.6 & 9.2 \\
\hline 5 & 95 & 30.2 & 27.8 & 7.8 \\
\hline 10 & 96 & 28.2 & 26.5 & 8.3 \\
\hline 10 & 95 & 33.3 & 24.1 & 10.5 \\
\hline \multirow[t]{3}{*}{30} & 96 & 34.8 & 21.8 & 10.0 \\
\hline & $\mathrm{L}^{*} \mathrm{Q} * * *$ & $\mathrm{~L}^{*} \mathrm{Q} * * *$ & $\mathrm{~L}^{* * *} \mathrm{Q} * * *$ & NS \\
\hline & & Texas & & \\
\hline Control & 94 & 45.8 & 34.4 & 9.0 \\
\hline 5 & 96 & 38.1 & 25.9 & 8.0 \\
\hline 10 & 96 & 38.0 & 28.2 & 8.0 \\
\hline \multirow{2}{*}{30} & 97 & 32.9 & 23.9 & 8.0 \\
\hline & $\mathrm{L} * \mathrm{Q} *$ & $\mathrm{~L}^{* *} \mathrm{Q} * *$ & $\mathrm{~L}^{* * *} \mathrm{Q} * * *$ & NS \\
\hline
\end{tabular}

${ }^{\mathrm{z} C o n t r o l s ~ w e r e ~ s o a k e d ~ f o r ~} 10 \mathrm{~min}$ in reverse-osmosis water.

${ }^{\mathrm{y}}$ Significance of linear (L) or quadratic (Q) regression: NS, ${ }^{*}, * *, * * *$ denotes nonsignificant or significant at $P \leq 0.05,0.01$, or 0.001 , respectively. 